\title{
Preliminary Studies on the Proppant Embedment in Baltic Basin Shale Rock
}

\author{
Mateusz Masłowski ${ }^{1} \cdot$ Małgorzata Labus ${ }^{2}$ (D)
}

Received: 2 June 2020 / Accepted: 13 February 2021 / Published online: 3 March 2021

(c) The Author(s) 2021

\begin{abstract}
Proppant embedment is a serious issue that reduces fracture width and conductivity. The paper presents the results of experiments on embedment phenomena on a shale rock from the region of the Baltic Basin, which is regarded as an unconventional gas deposit. A novel laboratory imaging procedure was implemented to the proppant embedment visualization. The tests were performed for conditions corresponding to the average reservoir conditions occurring in the studied deposit formation. The parameters characterizing damage of the surface of the fracture faces by the grains of proppant material, after the application of axial compressive stress to two shale core samples with proppant placed in between, are presented. The tests were carried out for rock samples pre-saturated with fracturing fluid. The obtained results of relatively low total effective penetration depth of proppant grains into the walls of the fracture $(0.293 \mathrm{~mm})$, and high effective width of fracture with proppant material after hydraulic fracturing (87.9\%), indicate the proper selection of proppant and fracturing fluid for the properties of the rock and the reservoir conditions. The results of the experiments present a range of embedment parameters, that have not been widely described before. The test procedure presented in the article is a good method for assessing the vulnerability of a deposit rock to embedment phenomenon.
\end{abstract}

Keywords Proppant embedment $\cdot$ Shale $\cdot$ Surface roughness $\cdot$ Hydraulic fracturing $\cdot$ Mechanical properties

\section{Introduction}

Hydrocarbons exploitation from unconventional deposits, including shale gas and tight-gas sandstone is carried out by vertical, directional, horizontal and multi-bottom drilling. To conduct effective hydrocarbon extraction from these types of deposits, it is necessary to perform hydraulic fracturing operations. This is to release the hydrocarbons enclosed in them and extract them from the outermost part of the deposit. It should be noted here that unconventional deposits are characterized by low permeability and low porosity of the host rock. Therefore, it is important to properly choose the hydraulic fracturing technology, which is designed to

Małgorzata Labus

malgorzata.labus@polsl.pl

Mateusz Masłowski

mateusz.maslowski@inig.pl

1 Oil and Gas Institute, National Research Institute, 25A Lubicz St, 31-503 Krakow, Poland

2 Institute for Applied Geology, Silesian University of Technology, 2 Akademicka St, 44-100 Gliwice, Poland reduce damage to the fracture wall surface, resulting in a reduction of hydrocarbon flow from the rock to the fracture with the proppant material and subsequently to the well. Hydraulic fracturing has been a standard technology used in the hydrocarbon industry for more than 50 years to overcome effects of formation damage and low rock permeability and to increase the productivity of a reservoir beyond its natural level (Economides Nolte 2000). The main advantage of hydraulic fracturing is that it allows the extractions of natural oil or gas from impervious tight formations (Donaldson et al. 2013). The history of knowledge in hydraulic fracturing, as well as current technologies in proppant-based stimulation technologies are broadly described by Bandara et al. (2019). Hydraulic fracturing involves the injection of a high-pressure fluid into the formation to create fractures, to release the enclosed hydrocarbons, and to ensure hydraulic conductivity in the created fractures to achieve a continuous high production rate. Commonly, a propping agent (sieved sand or ceramic spheres) is added to the injected fluid to avoid complete fracture closure after pressure release (Weaver et al. 2007). 
The technology of hydraulic fracturing of hydrocarbon deposits, and the range of created and backfilled fractures, depends on many factors. These include, among others: properties of the reservoir rock and surrounding layers, thickness of the deposit, temperature and deposit pressure, the exploited medium, the contact of the deposit with the well face (Morales 2012; Smith and Montgomery 2015).

The formation of a fracture in the deposit occurs if one of the wellbore wall stress components exceeds the tensile or shear strength of the formation rock. These stresses arise as a result of increasing the pressure of the fracturing fluid injected into the reservoir rock above the fracturing pressure of the bed. The resulting cracks (fissures) are filled with proppants which prevents the fracture from completely closing under closure stress when pumping stops (Masłowski 2015; Masłowski et al. 2018, 2019; Morales 2012; Sato et al. 1998). As a result, gas and oil flow from the reservoir to the well is obtained, as shown in Fig. 1 (Masłowski and Czupski 2014; Terracina et al. 2010).

Hydraulic conductivity is influenced by mechanical stress on proppant pack, leading to proppant crushing and embedment, and as a consequence, to reduction of fracture width and fines production. According to the American Petroleum Institute (API 1989) and Alramahi and Sundberg (2012), proppant damage mechanisms may cause up to $99 \%$ reduction of fracture pack conductivity (Tang et al. 2018). The most important proppant damage mechanisms include proppant crushing, embedment (Morales 2012; Sato et al. 1998; Masłowski et al. 2018, 2019; Reinicke et al. 2006, 2010; Czupski 2013), fine generation and migration, proppant diagenesis and proppant flowback.

The phenomenon of squeezing out the rock material resulting from embedment of proppant grain into the rock is also described. The above mentioned phenomena are presented in Fig. 2. An additional issue associated with proppant embedment is the creation of formation fines (spalling), which can migrate and cause additional loss of fracture conductivity (Terracina 2010).

The nature of the rock surface deformation can be classified into elastic or plastic deformation, depending on the material properties. The increase in the plasticity of the rock

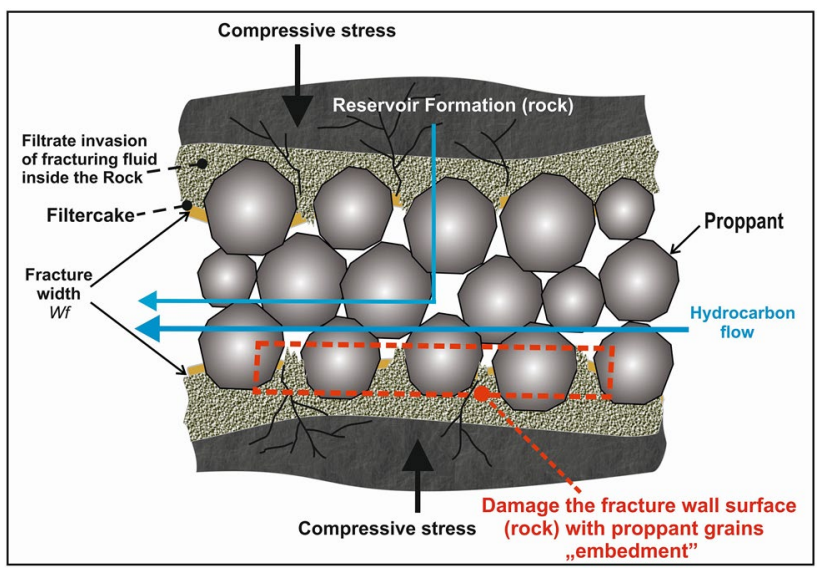

Fig. 2 The phenomena affecting damage to the fracture face surface during hydraulic fracturing of hydrocarbon deposits

causes the pressing of the proppant grains into the fracture face. It takes place after the hydraulic fracturing operation, when the fracturing pressure decreases and the increase of the compressive stress influence on the gap filled with the proppant material. These stresses come from the rock mass. In the case of many proppant grains being pressed into the fracture face, its effective filling with proppant material in case of its different surface concentration (Bandara et al. 2019; Masłowski 2015; Masłowski et al. 2018; Masłowski 2019; Masłowski et al. 2016; Masłowski and Biały 2016; Sato et al. 1998). Deng et al. (2014) used newly developed discrete element method to numerical simulation of shaleproppant interaction, and found that the higher the concentration of the proppant is, the smaller the embedment depth.

The amount of damage to the surface of the fracture face by the compressed proppant grains into the deposit rock is influenced by, among others: rock type, geomechanical properties of the rock, type of proppant material, compressive stress values in the deposit, compression stress time, type of fracturing fluids and reservoir fluids, temperature, exploitation technology (Alramahia and Sundberg 2012; Reinicke et al. 2006; Reinicke et al. 2010; Bandara et al. 2019; Lacy et al. 1997; Akrad et al. 2011; Ghassemi and
Fig. 1 Scheme of hydraulic fracturing treatment with proppant in unconventional shale gas deposits

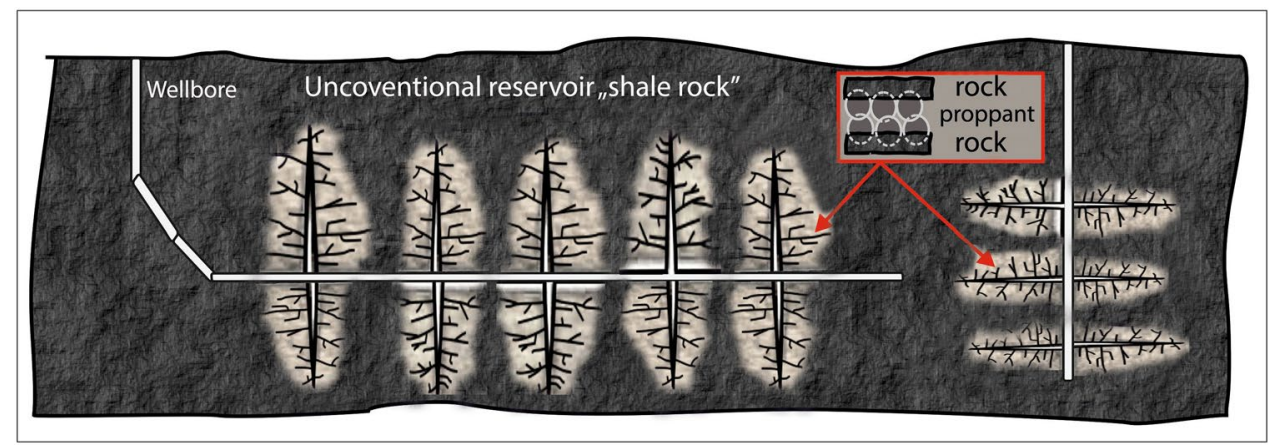


Suarez-Rivera 2012; Mueller and Amro 2015; Chen et al. 2018). Tang et al. (2018) list a range of factors influencing proppant performance, e.g.: proppant type, size, shape and mechanical properties, bulk density. The amount of proppant injected with the fracturing fluid, or proppant concentration, also has a significant influence on its performance in the fracture network. The numerical studies performed by Mueller and Amro (2015) have additionally shown that the proppant size distribution has a significant effect on the embedment and the closure of the propped fracture. Proppants can embed into the fracture face especially in soft shale formations, as presented by Terracina et al. (2010) on the example of some shale formations of the USA (Fayetteville, Bakken and Haynesville). The fracture damage may be impacted by proppant-diagenesis, which evolves, as a result of mineral dissolution, transport and re-precipitation in the particle interstices (Lee et al. 2010).

Understanding the hydraulic and mechanical interactions in the rock-proppant system is indispensable for achieving sustainable long-term productivity from a reservoir. Regardless of the many advancements which took place in the research sector during the last few decades, the occurrence of proppant embedment in underground formations has been an unavoidable issue in unconventional oil/gas and geothermal extraction processes (Chen et al. 2018).

Systematic studies on long term fracture conductivity, the impact of fracturing fluid leak-off, gel damage, non-Darcy flow, multiphase flow, proppant crushing and embedment have been done by Baree and Conway (2009) and Barree et al. (2018). Some tests were also carried out to find out how dry rock and rock soaked in fracturing fluids behave. The area which is highly influenced by the treatment fluid can show great differences in the mechanical behavior in comparison to the untreated area. Moreover the fluid composition affects the indentation hardness of the samples, which will affect the depth of embedment (Akrad et al. 2011; Mueller and Amro 2015). This is of great importance, especially in silty-clay rocks, which are characterized by high percentage of clay minerals (above 40\%), high degree of plasticity, low Young's modulus and a high Poisson's ratio.

The phenomenon of proppant embedment was first studied for carbonate and sandstone formations, but the following demands of oil and gas industry resulted in the research being redirected also to shale and other tight rock formations. To meet the thriving energy demand (Speight 2016). The fracture conductivity and closure pressure data of different formations (siltstone, mudstone, conglomerate, and shale) were obtained by Wen et al. (2007), and Gou et al. (2017), to investigate the effect of embedment. As it was summarised by Bandara et al. (2019), the above mentioned research shows that, as the closure pressure increases, proppant embedment severely affects all types of formations, showing a gradual decrease in fracture conductivity. When fracture closure pressure is increased from 30 to $90 \mathrm{MPa}$, a significant reduction in fracture conductivity is observed in siltstone $(78.42 \%)$, mudstone $(81.89 \%)$ and conglomerate $(91.55 \%)$ formations. In case of shale rock, the fracture conductivity is reduced by $78.05 \%$ when the closure pressure increases from 7 to $70 \mathrm{MPa}$ (Gou et al. 2017). The overview of the current state of knowledge about the phenomenon of embedment indicates that despite the formation type, the individual formation characteristics play a significant role in determining the impact of proppant embedment (Bandara et al. 2019).

In our research work we focus on a shale formation from the region of the Baltic Basin (Poland) which is regarded as an unconventional gas deposit. Depending on their origin, the texture of shales is between soft clay and hard cemented rocks (Gutierrez and Nygard 2008). The mineralogy of shale samples is important to understand its impact on the changes in rock mechanical properties and corresponding proppant embedment (Singh 2019). The former experience of the authors' research group enables the appropriate selection of proppant material parameters (Masłowski 2015; Masłowski et al. 2018; Masłowski et al. 2019; Masłowski Czupski 2019; Masłowski et al. 2016; Masłowski and Biały 2016). Table 5, placed in chapter 4 (Discussion), presents selected parameters of experimental studies performed by the research group of Oil and Gas Institute (Masłowski 2015; Masłowski et al. 2018, 2019; Masłowski and Biały 2016) and other researchers (Terracina 2010) on shale rocks. The shale rock examined in the case of studies (Masłowski 2015; Masłowski et al. 2018, 2019; Masłowski and Biały 2016) was sampled in the Lublin Region (Fig. 3) from Silurian (Wenlock) strata.

The presented study is planned as a preliminary one, focused on experimental procedure of proppant embedment imaging, which will enable, in the future to find more embedment parameters.

\section{Materials and Methods}

The analyses were performed at the Oil and Gas Institute-National Research Institute (O\&GI-NRI) in Cracow (Poland). For petrographic observations, the Zeiss Axioskop polarizing microscope was used. The XRD analyses were performed with use of Philips X'Pert MPD diffractometer (Cu lamp max. $2500 \mathrm{~W})$. Quality analysis was executed under the following measurement conditions: excitation voltage $40 \mathrm{kV}$, anode current $34 \mathrm{~mA}$, exposure time $1.0 \mathrm{~s}$, measuring step $0.05^{\circ}(2 \theta)$, measuring range $3-64^{\circ}(2 \theta)$. The quantitative analysis was possible thanks to the use of an internal standard $(\mathrm{ZnO})$.

Total organic carbon content in the samples (TOC), which is generally regarded as an indicator of kerogen and bitumen 
Fig. 3 Location of the Lower Paleozoic Baltic Basin in the northern part of Poland [after 26, changed]. Explanations: EEC East European Craton, $S P W$ Płock-Warszawa Zone, $S B N$ Biłgoraj-Narol Zone, $E E C$ western slope of the East European Craton with the background of the main tectonic units of the central and northern Europe

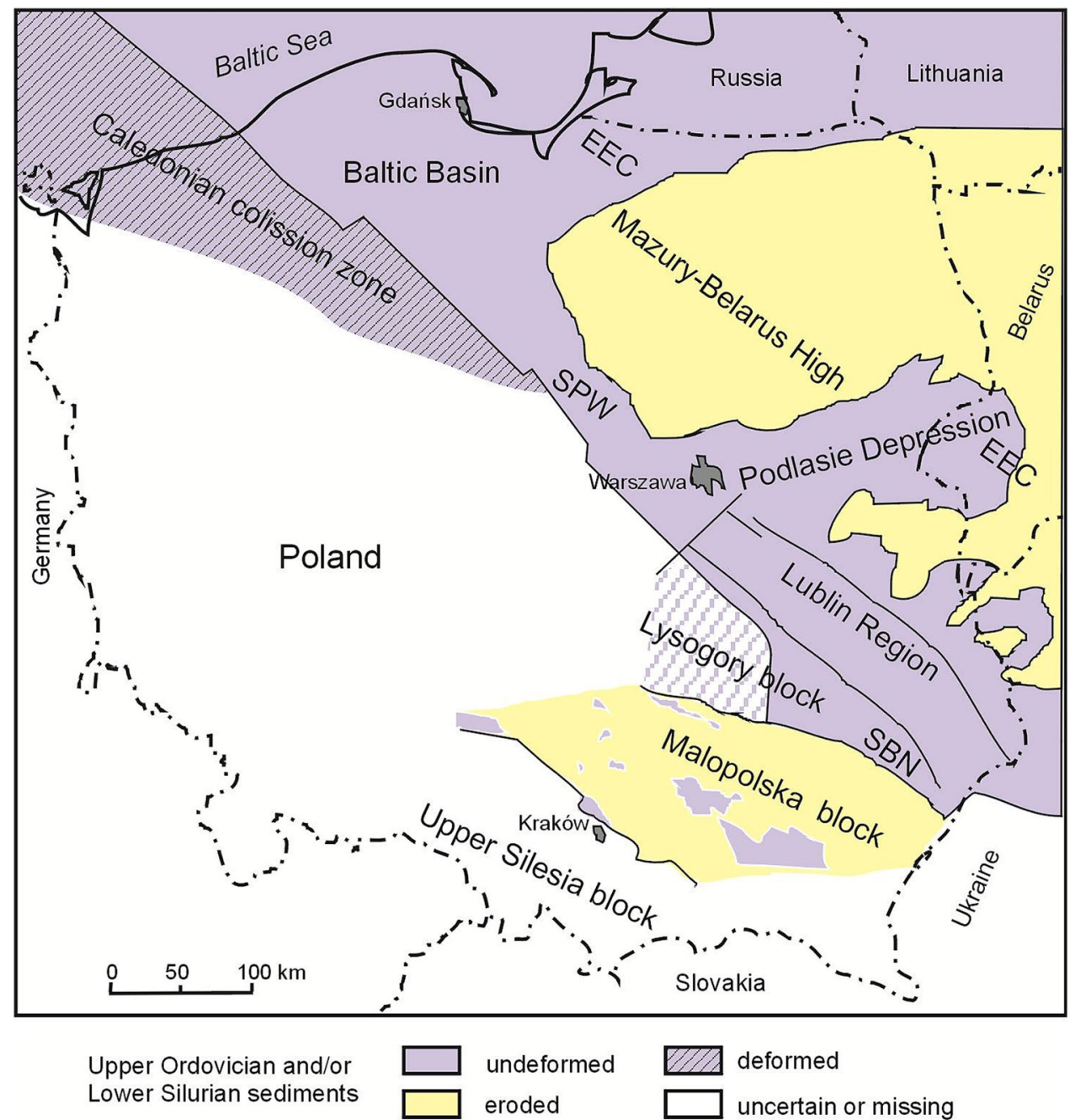

amounts in the rock, was determined using of the Rock-Eval pyrolysis method.

The dynamic moduli of the examined rock (Young' modulus and Poisson's ratio) were laboratory determined by measuring pulse velocities of $\mathrm{P}$-wave $\left(V_{\mathrm{p}}\right)$ and $\mathrm{S}$-wave $\left(V_{\mathrm{s}}\right)$ with use of apparatus AVS-700 (Vinci Technologies). This equipment allows the measurement of acoustic velocity of a core sample under a wide range of pore and confining pressures. The examinations were performed under assumed pressure and temperature conditions. Based on the obtained dynamic parameters, the brittleness of the rock was calculated according to method described by Grieser and Bray (2007).

\subsection{Rock Sample Description}

The rock samples were collected from boreholes (from a depth of about $3300 \mathrm{~m}$ ), located in the Baltic Basin Craton. The Baltic Basin, which extends from Northern Poland to Lithuania, was recently one of the most explored areas for unconventional shale gas in Europe (Fig. 3). The significant unconventional gas and oil resources are accumulated in laterally extensive, organic rich shale rocks, which stratigraphic position extends from the Late Llanwirnian to Wenlock (Poprawa, 2010). The analysed shale rocks sample belongs to the Llandovery strata which is an organic rich shale formation. The lower part of the Llandovery section on major part of the basin is characterized by high TOC contents (Klimuszko 2002). The highest measured TOC contents reaches $20 \%$, while average TOC contents of the Llandovery shale are usually equal to $1-3 \%$ (Poprawa 2010).

Assuming that reserves of "shale gas" type occur in Poland mostly at medium depths of $2000 \div 4000 \mathrm{~m}$, it should be expected that compressive stresses prevailing there, are between 41.4-89,7 MPa (6000-13,000 psi), and the reservoir temperature is of the order of $60-120{ }^{\circ} \mathrm{C}$. For the tested sample, taken from the depth of $3200 \mathrm{~m}$, the following deposit parameters were adopted: temperature $96{ }^{\circ} \mathrm{C}$, and compressive stress of $65.5 \mathrm{MPa}$ (9500 psi). Taking into account these parameters, the dynamic Young's modulus $E$ 
was determined as $18.1 \mathrm{GPa}$, and Poisson's ratio $v=0.31$. Using these parameters, the brittleness was calculated as $28 \%$. The Young's modulus value is lower than $24 \mathrm{GPa}$, which was considered as a limit value for exploitation of perspective shale rock in the Polish deposit conditions (Kasza 2013). The brittleness is relatively low. The rock with an increased content of clay minerals and increased plasticity (brittleness below 30\%) is characterized by significantly reduced susceptibility to hydraulic fracturing (Rickman et al. 2008). Hence the rock requires better filling with proppant material during fracturing.

The examined rock can be classified as argillaceouscalcareous mudstone. It is dark gray, laminated, exhibiting a clear cleavage. The detrital grains are quite common, which is visible in polarizing microscope image (Fig. 4). The maximum grain size is characteristic for medium silt. The following minerals were microscopically detected: clay minerals (illite, chlorite), quartz, calcite, plagioclase and iron sulphides (pyrite). The other opaque grains (apart from iron sulphides) represent organic matter, mostly visible as round spots (Fig. 4b).

The XRD analysis reveals the following mineral content: quartz-23.2\%, feldspars (plagioclase and K-feldspar)-6.2\%, carbonates (including calcite, dolomite and ankerite) $-13.0 \%$, mica and clay minerals-54.0\%, and iron sulphides (pyrite and marcasite)-3.6\% (Fig. 5). Clay species are dominated by illite (18.0\%); with a lower share of mixed-layer illite-smectite (3.3\%), chlorite $(4.0 \%)$ and kaolinite (3.6\%). The high content of clay minerals (> 50\%) allows to classify the examined rock into shales in the traditional sense, as defined in geology (Akrad et al. 2011; Denney 2012). The organic matter content is not detectable by XRD method. TOC content determined by Rock Eval analysis is relatively high: $5.56 \%$, which is also confirmed by thin section image, where organic matter concentration is parallel to the rock layers (Fig. 4b).

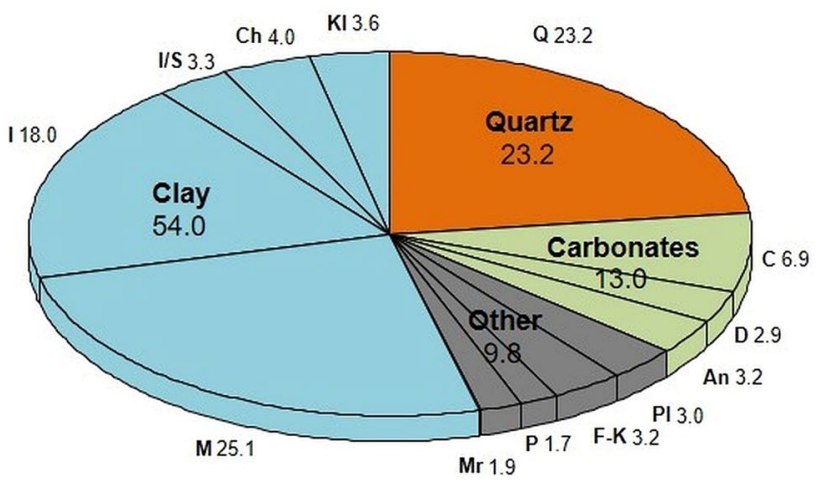

Fig. 5 Mineral composition of shale, determined by XRD method. Explanations: $Q$ quartz, $C$ calcite, $D$ dolomite, $A n$ ankerite, $P l$ plagioclase, $F$ - $K$ K-feldspar, $P$ pyrite, $M r$ marcasite, $M$ mica and illite group minerals, $I$ illite, $I / S$ illite/smectite, $C h$ chlorite, $K l$ kaolinite. Values given in wt.\%

\subsection{Fracturing Fluid and Proppant Material}

The technology of cross-linked fracturing fluids and proppant with a larger grain diameter of $0.850 \div 0.425 \mathrm{~mm}$ is usually used to fracture the rocks with an increased content of clay minerals and increased plasticity (Rickman 2008). Fracturing fluid used in our experiment was crosslinked natural polymer 30\# (Fig. 6b). The composition of the fluid was as follows: tap water, biocide, gelling agent-natural polymer (guar) in powder $3.6 \mathrm{~kg} / \mathrm{m}^{3}$, clay minerals stabilizer and clay swelling inhibitor, nanoemulsion, $\mathrm{pH}$ buffer, crosslinker (boron compounds), $2.01 / \mathrm{m}^{3}$, viscosity breaker, $2.4 \mathrm{l} / \mathrm{m}^{3}$. As proppant material-intermediate strength ceramic proppant ISP 20/40 was used, Fig. 6c). Proppant grain size was between 0.850 and $0.425 \mathrm{~mm}$; mean grain size was $0.673 \mathrm{~mm}$. Bulk density of proppant was $1.89 \mathrm{~g} /$ $\mathrm{cm}^{3}$. The proppant have an average sphericity of 0.88 and an average roundness of 0.85 .
Fig. 4 Thin section image of analysed shale rock. a crosspolarized light; b plane-polarized light
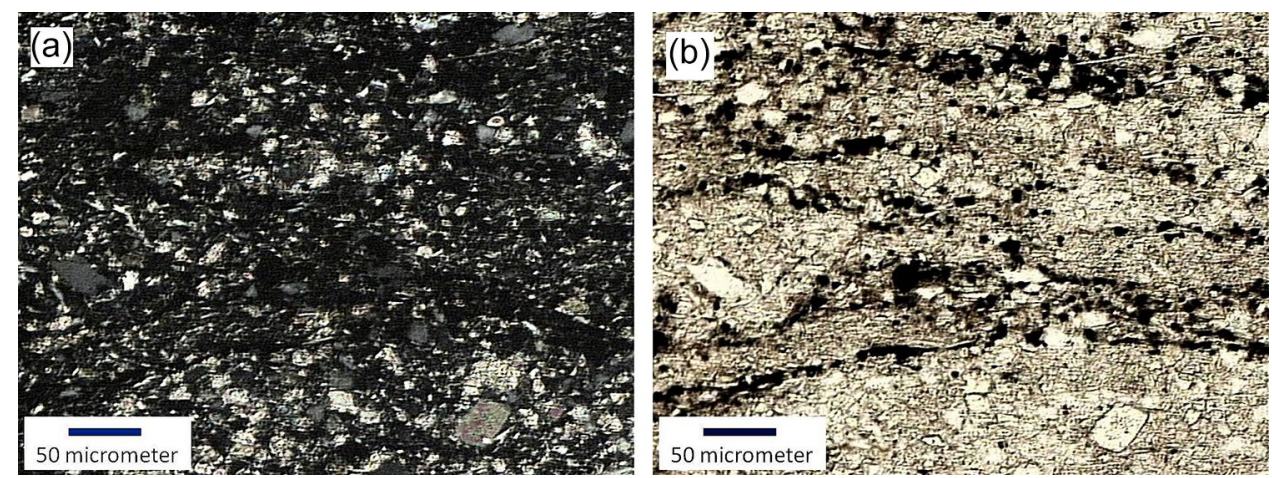
Fig. 6 Experimental material a shale rock, $\mathbf{b}$ fracturing fluid, $\mathbf{c}$ ceramic proppant ISP 20/40
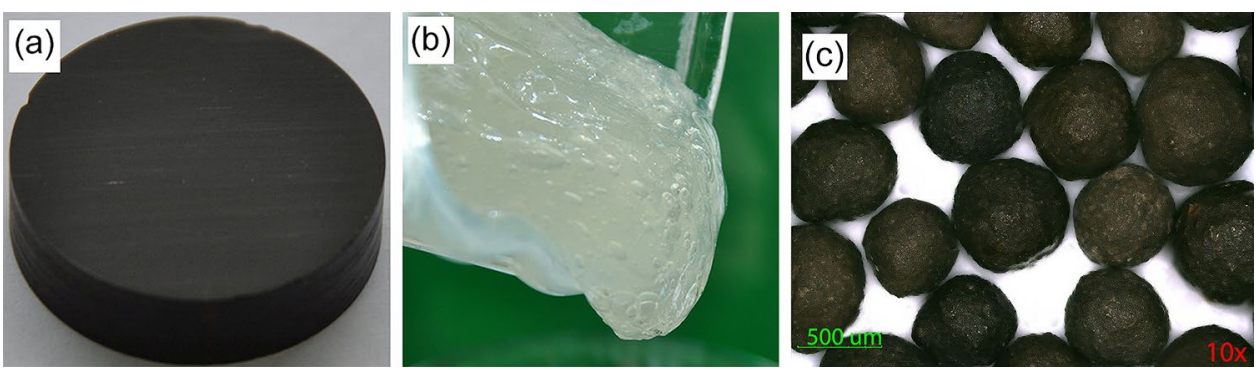
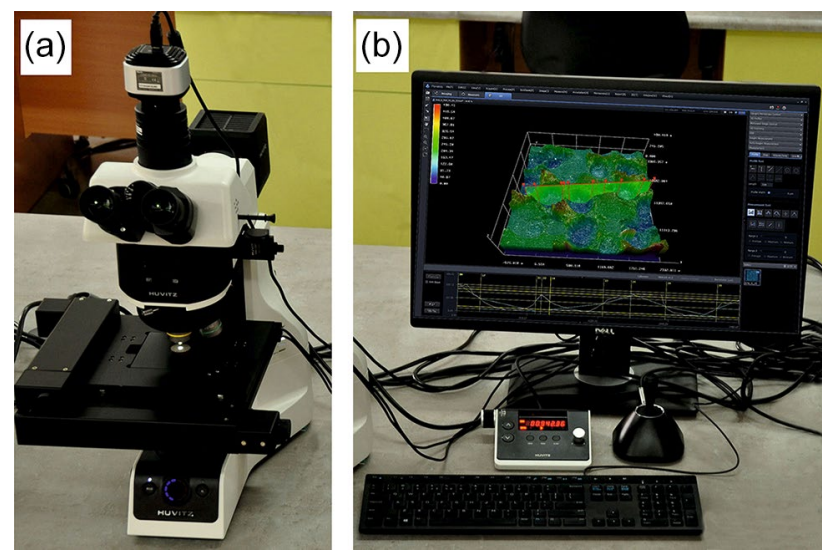

Fig. 7 Optical microscope a with stereoscopic software, b to imaging selected rock face

\subsection{Methodology of Embedment Examination}

To examine the embedment phenomenon the research methodology, developed in Oil \& Gas Institute-National Research Institute, was used (Masłowski 2015; Masłowski et al. 2018, 2019; Masłowski and Czupski 2019). According to this methodology, the cylindrical rock samples of a diameter of $2.54 \mathrm{~cm}$ are cut out in a direction perpendicular to the bedding plane (Fig. 6a). The face surfaces of the cylindrical rock samples are ground and a roughness coefficient $R_{a}$ is determined for their face. The roughness is determined with the use of a stereoscopic microscope Huvitz HRM-300 (Fig. 7) enabling digital imaging of the face of the rock thanks to the PANASIS software.

The method of determination of the surface roughness and the measurements are presented in Fig. 8 (Masłowski 2015; Masłowski et al. 2018, 2019; Masłowski and Czupski 2019; Masłowski and Biały 2016).

A digital image of the surface is made for selected areas, and then for each of them the average roughness from the roughness profile along the selected (at least three measuring sections) is determined, as well as Eq. 1 (Masłowski 2015; Masłowski et al. 2018, 2019; Masłowski and Czupski 2019; Masłowski and Biały 2016).

$R_{a}=\frac{\sum_{i=1}^{n_{v}} H_{v_{i}}+\sum_{i=1}^{n_{p}} H_{p_{i}}}{n_{v}+n_{p}}$,

where: $R_{a}$ roughness of the profile surface along the measurement section $(\mathrm{mm}) ; H_{p}$ is peak eight $(\mathrm{mm}) ; H_{v}$ valley depth $(\mathrm{mm}) ; n_{p}$ number of all peaks $(-) ; n_{v}$ number of all valleys (-).

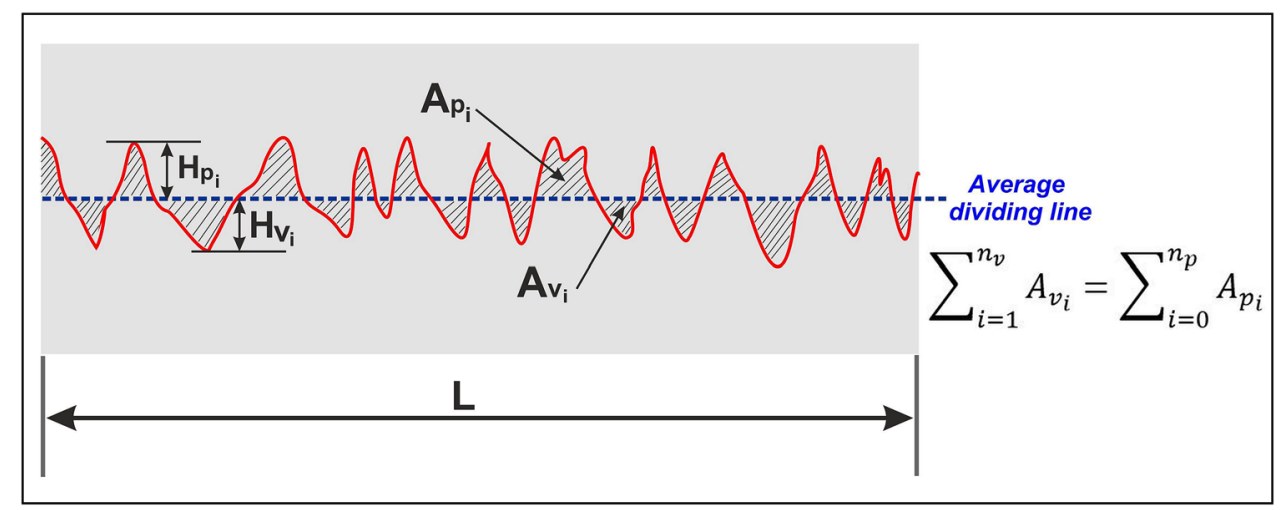

Fig. 8 An example of the surface roughness profile along the measurement section for the selected area on the surface of the fracture face. Explanations: $H_{v_{i}}$ the valley depth $(\mathrm{mm}), H_{p_{i}}$ the peak height $(\mathrm{mm}), n_{v}$ the total number of valleys $(-), n_{p}$ the total number of peaks (-), $A_{v_{i}}$ individual area of the surface between a valley curve and an average dividing line $\left(\mathrm{mm}^{2}\right), A_{p_{i}}$ individual area of the surface between a peak curve and an average dividing line $\left(\mathrm{mm}^{2}\right), L$ length of the measurement section $(\mathrm{mm})$ 
The average primary roughness $R_{a}$ was determined as the arithmetic average of five selected areas on the face of the tested core, from three profiles running across the studied area. The roughness $R_{a}$ measurement of the average surface roughness of the fracture face (face of the cylindrical sample), will prove that the samples are uniformly prepared and their surface is suitable for further research and analysis.

The tests were performed in two experiment cycles: (1) for rock saturated with fracturing fluid, (2) for steel plugs, of a hardness greater than 43 in Rockwell scale C (HRC).

The procedure of test no. 1 consists of the initial saturation of rock samples with fracturing fluid (Fig. 6b). The rock samples were saturated for $105 \mathrm{~min}$ in a special chamber for core saturation (Fig. 9a), at a temperature of $96^{\circ} \mathrm{C}$, under pressure of $6.9 \mathrm{MPa}$ (equivalent to an effective stress at about $3200 \mathrm{~m}$ depth, as it was determined before for the reservoir conditions). Then the soaked samples were placed, together with proppant (between two rock cylinders) in the cylindrical chamber for simulation of the embedment phenomenon (Fig. 9b), where they are subjected to a given compressive stress, at a given temperature, for a specified period of time (Table 1). The surface concentration of proppant, of the order of $4.88 \mathrm{~kg} / \mathrm{m}^{2}$, corresponds to the proppant (grain size 20/40 mesh) injected by the cross-linked fracturing fluid into the resulting fracture in shale rock with high plasticity.

Test no. 2 was performed on cylindrical steel plugs (instead of rock), which are treated as a resistant material, that is not subject to embedment phenomenon. The other parameters of test no. 2 correspond to the parameters and conditions adopted for test no. 1.

The chamber is equipped with a hydraulic press with a linear variable differential transformer (LVDT), which enables fissure measurement. After the assumed time elapsed, the compressive stress was removed, the chamber was unscrewed and the face surfaces of the cylindrical rock samples (fracture
Table 1 Experimental conditions

Tests conditions

Temperature, $\left({ }^{\circ} \mathrm{C}\right)$

96.0

Proppant concentration, $\left(\mathrm{kg} / \mathrm{m}^{2}\right) \quad 4.88$

Compressive stress, (MPa) $\quad 65.5$

Time of compressive stress exposure, (hours)

faces) examined under a stereoscopic microscope, and the 3D images are obtained (Fig. 7).

The analysis of the surface damage of the rock cores (simulating fracture faces) by the proppant grains consists in determining the total average depth embedment of the proppant grains in the rock $H_{e}$ (valley depth), the total average height of the rock material squeezed out from the rock $H_{w}$ (peak height) and the total average damage of the fracture face $\mathrm{DF}_{e}$ and $\mathrm{DF}_{w}$.

Digital imaging of the fracture surface in $3 \mathrm{D}$ is performed for several selected areas. Then, for each of them are determined: the average depth and average percentage damage, basing on selected profiles along several measurement sections. The method for determining the depth of proppant embedment $H_{e}$, the height of the squeezed upwards rock material $H_{w}$, and the damage to the fracture face along the measurement section $\mathrm{DF}_{e}$ and $\mathrm{DF}_{w}$ is presented in Fig. 10, and following equations $[8-10,19]$.

The average depth of proppant embedment in the fracture face of the profile along the measurement section $H_{e}(\mathrm{~mm})$ is determined according to the following equation:

$H_{e}=\frac{\sum_{i=1}^{n_{e}} H_{e_{i}}}{n_{e}}$
Fig. 9 The scheme of the embedment test procedure: a chamber for rock saturation; $\mathbf{b}$ hydraulic press with heating cylindrical chamber for simulation of formation conditions (a)

(b)

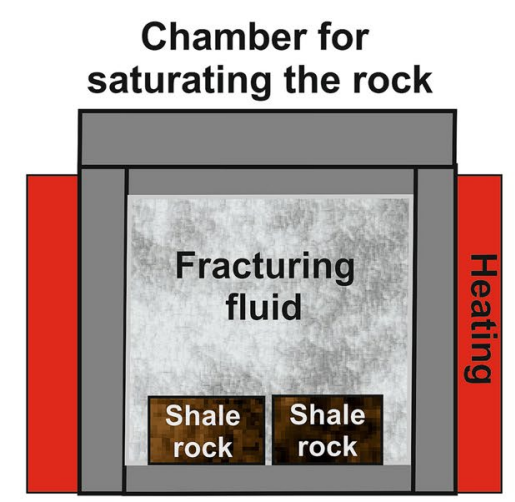

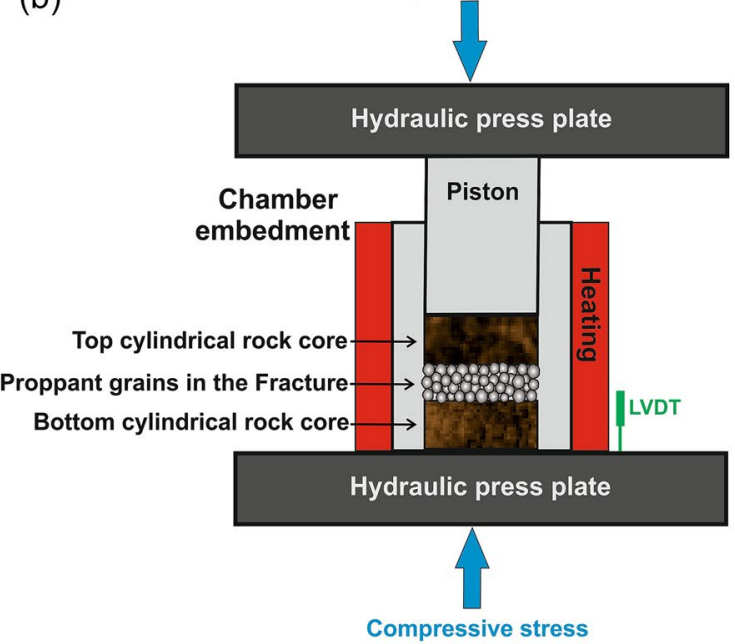




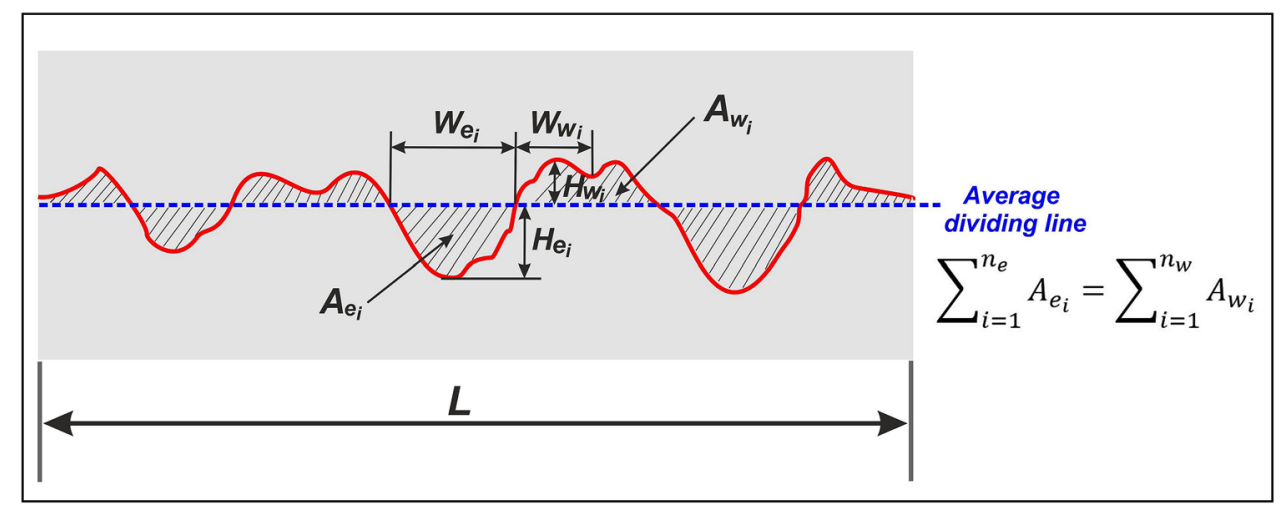

Fig. 10 Model of rock surface affected by proppant embedment. Explanations: $H_{e_{i}}$ individual depth of proppant embedment (valley depth) $(\mathrm{mm}), H_{w_{i}}$ individual height of the rock material squeezed out (peak height) $(\mathrm{mm}), W_{e_{i}}$ individual width of proppant embedment (valley width) (mm), $W_{w_{i}}$ individual width of the rock material squeezed out (peak width) (mm); $A_{e_{i}}$ individual area of embedment

where: $H_{e_{i}}$ individual depth embedment of a proppant grain into the rock (valley depth) (mm); $n_{e}$ number of all valleys along the measurement section (dimensionless value).

The total average depth of proppant embedment for the fracture $\left(H_{e_{t}}(\mathrm{~mm})\right)$, is determined as the sum of average depth of proppant embedment in the top fracture face $H_{e_{T \cdot a}}$ (arithmetic average for selected areas), and average depth of proppant embedment in the bottom fracture face $H_{e_{B, a}}$.

The average height of the rock material squeezed out from the rock (peak height) along the measurement section $H_{w}(\mathrm{~mm})$ is determined according to the following equation:

$H_{w}=\frac{\sum_{i=1}^{n_{w}} H_{w_{i}}}{n_{w}}$,

where: $H_{w_{i}}$ individual height of the rock material squeezed out from the rock (peak height) (mm); $n_{w}$ number of all peaks along the measurement section (dimensionless value).

The total average height of the rock material squeezed out from the rock for the fracture $H_{w_{t}}(\mathrm{~mm})$, is determined as the sum of average peak height on the top fracture face $H_{w_{T a} a}$ (arithmetic average for selected areas), and average peak height on the bottom fracture face $H_{w_{B, a}}$.

The damage of the fracture face profile, as a result of embedment of proppant grains into rock face, along the measurement section $D F_{e}(\%)$ is determined according to the following equation:

$D F_{e}=\frac{\sum_{i=1}^{n_{e}} W_{e_{i}}}{L} \cdot 100$,

where: $W_{e_{i}}$ individual width embedment of a proppant grain into the rock (valley width) $(\mathrm{mm}) ; L$ length of the measurement section (mm). proppant of the surface between a embedment curve and an average dividing line $\left(\mathrm{mm}^{2}\right), A_{w_{i}}$ individual area of rock material squeezed out from the rock of the surface between a rock material squeezed curve and an average dividing line $\left(\mathrm{mm}^{2}\right), L$ length of the measurement section $(\mathrm{mm})$

The total damage of the fracture face $\mathrm{DF}_{e_{t}}(\%)$ is determined as an arithmetic average of average percentage damage of the top and bottom fracture faces $\mathrm{DF}_{e_{T, a}}$ and $\mathrm{DF}_{e_{B, a}}$.

The damage of the fracture face profile, as a result of rock material squeezing out from the rock face, along the measurement section $\mathrm{DF}_{w}(\%)$ is determined according to the following equation:

$\mathrm{DF}_{w}=\frac{\sum_{i=1}^{n_{w}} W_{w_{i}}}{L} \cdot 100$,

where: $W_{w_{i}}$ individual width of the rock material squeezed out from the rock (peak width) $(\mathrm{mm}) ; L$ length of the measurement section $(\mathrm{mm})$.

Analogously to the method of calculation of $\mathrm{DF}_{e_{t}}$, total damage of the fracture face profile, as a result of rock material squeezing out from the rock face $\mathrm{DF}_{w_{t}}(\%)$ is determined as an arithmetic average of average damage of the top and bottom fracture face $\mathrm{DF}_{w_{T, a}}$ and $\mathrm{DF}_{w_{B, a}}$.

The effect of the embedment phenomenon on the effective width of the fracture packed with proppant after exposing to compression stress is determined using Eqs. (6) and (7):

$W_{f}=W_{f_{m}}-\left(H_{e_{t}}+H_{w_{t}}\right)$

where: $W_{f}$ fracture width packed with proppant, taking into account the embedment phenomenon $(\mathrm{mm}) ; W_{f_{m}}$ maximal fracture width packed with proppant, not taking into account the embedment phenomenon (mm).

$\mathrm{PRWF}=\frac{W_{f}}{W_{f_{m}}} \cdot 100$, 
where: PRWF percentage reduction of the width of fracture packed with proppant, taking into account the embedment phenomenon (\%).

The effective width of fracture EWF with packed proppant after hydraulic fracturing, expressed in $\%$, is determined according to Eq. (8).

$\mathrm{EWF}=100-\mathrm{PRWF}$.

In test No. 2, the maximum gap width $W_{f_{m}}$ of a crack filled with proppant, without the occurrence of embedment and without rock material impression, was determined, according to the test procedure presented earlier in this article. In this test, instead of rock cores, high-hardness steel cores were used, and the hydraulic press should be additionally equipped with an LVDT meter (Fig. 8b). Throughout the test under the conditions shown in Table 1, the width $W_{f_{m}}$ of the gap filled with proppant was measured. Proppant was placed between two steel cores. With use of the LVDT measurements (i.e. maximum fracture width), there was possible to take into account the amount of deformation of the test stand (i.e. hydraulic press, measuring chamber and steel cores).

\section{Laboratory Simulation of the Embedment Phenomenon}

\subsection{Results of the Simulation}

The tests were performed on cylindrical rock cores according to the test procedure described above. At the beginning, the average primary surface roughness was determined for both the top and bottom surface of the cylindrical rock sample.

The average primary roughness $R_{a}$ for the entire face of the upper rock surface (top fracture face) was $0.0004 \mathrm{~mm}$ $( \pm 0.0001 \mathrm{~mm})$, while for the bottom rock surface (bottom fracture face) it was $0.0003 \mathrm{~mm}( \pm 0.0001 \mathrm{~mm})$.

The parameters characterizing the damage to the fracture face of the rock cores (Fig. 10) were determined according to the given above test procedure, and presented in Tables 2 , 3 and 4 . The appearance of the rock samples, saturated with fracturing fluid, used to simulate damage to the surface of the fracture face, before the experiment, is shown in Fig. 11a, while the damaged faces of the cores (in test no. 1) are presented in Fig. 11b.
Table 2 Parameters characterizing the damage to the fracture face of the rock cores saturated with fracturing fluid
Table 3 Parameters characterizing the damage to the fracture face of the rock cores saturated with fracturing fluid

\begin{tabular}{|c|c|c|c|c|c|c|}
\hline Test no. & Core face & $\begin{array}{l}\text { Examined } \\
\text { area }\end{array}$ & $H_{e}(\mathrm{~mm})$ & $H_{e . a}(\mathrm{~mm})$ & $H_{w}(\mathrm{~mm})$ & $H_{w \cdot a}(\mathrm{~mm})$ \\
\hline \multirow[t]{10}{*}{1} & \multirow[t]{5}{*}{ Top } & 1 & 0.0932 & \multirow[t]{5}{*}{0.0850} & 0.0917 & \multirow[t]{5}{*}{0.0838} \\
\hline & & 2 & 0.0834 & & 0.0877 & \\
\hline & & 3 & 0.0854 & & 0.0747 & \\
\hline & & 4 & 0.0913 & & 0.0833 & \\
\hline & & 5 & 0.0716 & & 0.0818 & \\
\hline & \multirow[t]{5}{*}{ Bottom } & 1 & 0.0519 & \multirow[t]{5}{*}{0.0564} & 0.0555 & \multirow[t]{5}{*}{0.0678} \\
\hline & & 2 & 0.0598 & & 0.0655 & \\
\hline & & 3 & 0.0549 & & 0.0816 & \\
\hline & & 4 & 0.0591 & & 0.0851 & \\
\hline & & 5 & 0.0563 & & 0.0513 & \\
\hline
\end{tabular}

\begin{tabular}{|c|c|c|c|c|c|c|}
\hline Test no. & Core face & $\begin{array}{l}\text { Examined } \\
\text { area }\end{array}$ & $\mathrm{DF}_{e}(\%)$ & $\mathrm{DF}_{e . a}(\%)$ & $\mathrm{DF}_{w}(\%)$ & $\mathrm{DF}_{w \cdot a}(\%)$ \\
\hline \multirow[t]{10}{*}{1} & \multirow[t]{5}{*}{ Top } & 1 & 44.6 & \multirow[t]{5}{*}{42.4} & 31.7 & \multirow[t]{5}{*}{36.9} \\
\hline & & 2 & 43.9 & & 35.4 & \\
\hline & & 3 & 36.7 & & 38.2 & \\
\hline & & 4 & 45.2 & & 39.5 & \\
\hline & & 5 & 41.9 & & 39.7 & \\
\hline & \multirow[t]{5}{*}{ Bottom } & 1 & 46.0 & \multirow[t]{5}{*}{50.0} & 43.1 & \multirow[t]{5}{*}{42.7} \\
\hline & & 2 & 52.0 & & 37.1 & \\
\hline & & 3 & 55.9 & & 44.0 & \\
\hline & & 4 & 50.0 & & 43.4 & \\
\hline & & 5 & 46.0 & & 46.1 & \\
\hline
\end{tabular}


Table 4 Parameters of the damage of the fracture face by the proppant grains

\begin{tabular}{|c|c|c|c|c|c|c|c|c|c|c|}
\hline Test no. & Sample & $H_{e . a}(\mathrm{~mm})$ & $H_{e_{t}}(\mathrm{~mm})$ & $H_{w \cdot a}(\mathrm{~mm})$ & $H_{w_{t}}(\mathrm{~mm})$ & $W_{f}(\mathrm{~mm})$ & $D F_{e_{t}}(\%)$ & $D F_{w_{t}}(\%)$ & PRWF (\%) & EWF $(\%)$ \\
\hline 1 & $\begin{array}{l}\text { Rock saturated } \\
\text { with fracturing } \\
\text { fluid }\end{array}$ & 0.071 & 0.141 & 0.076 & 0.152 & 2.137 & 46.2 & 39.8 & 12.1 & 87.9 \\
\hline 2 & Steel plugs & 0 & 0 & 0 & 0 & 2.430 & 0 & 0 & 0 & 100.0 \\
\hline
\end{tabular}
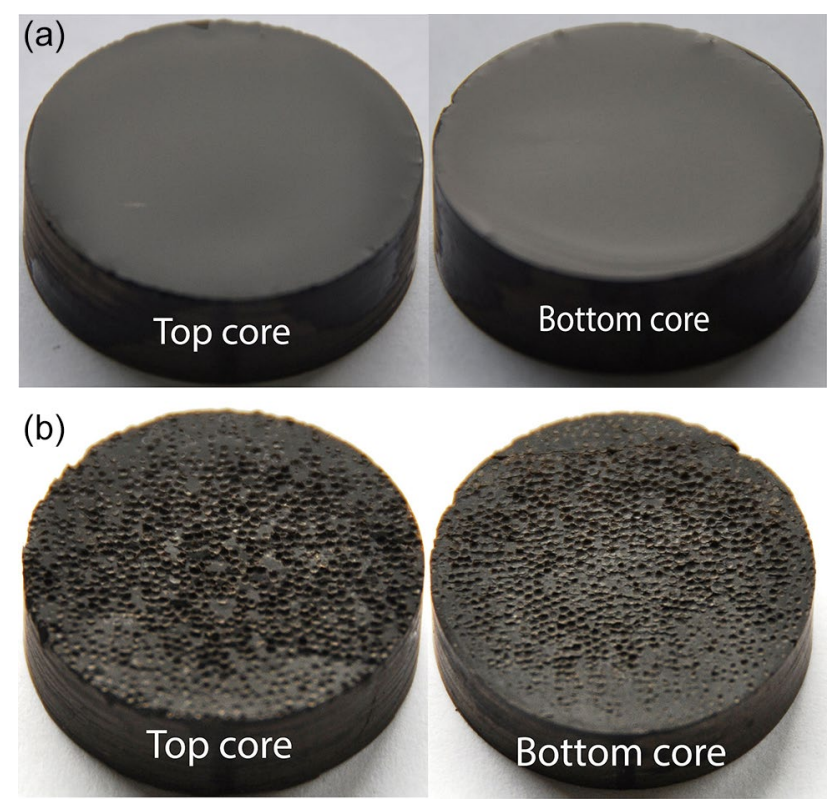

Fig. 11 Surface of the rock core samples: a saturated with fracturing fluid, before the embedment experiment; $\mathbf{b}$ damaged, after embedment experiment

Due to the large number of examined areas and profiles, a measurement of the embedment parameters is here presented, selected for one of the five analyzed areas, for the top face of the core sample (Figs. 12, 13 and 14).

Here it should be noted that the image analysis results are strongly dependent on the selection of the scanning line, the line direction, and the number of lines used for the analysis. Based on many years of experience, it was found that the number of 4 profile lines is representative for one analyzed area selected on the face of the core. In all analyses, carried in the current research, one similar direction of the tested profiles has been adopted. Of course, it should be noted that when squeezing the proppant grains and subsequently embedding them into the rock, there is an uneven impression of the rock material around the pressed grain. This is due to the lack of perfect sphericity of proppant grains and the phenomenon of their reorientation when compressing several layers of proppant grains.

To accurately assess the impact of embedment phenomena on rock material, and maximum width of the fracture

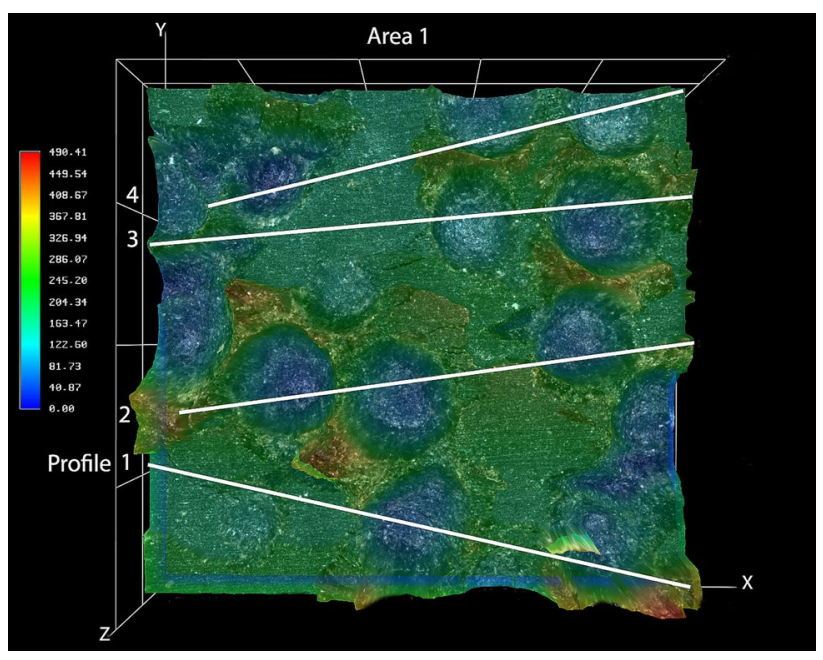

Fig. 12 The example of the area (area 1) analysed for surface roughness after embedment test for selected upper (top) core face (3D). The red colour represents highest elevated part while blue shows the depressed features on rock surface

packed with ceramic proppant of specific size, a laboratory calibration on steel specimens was performed. This test (test no. 2) enabled obtaining the maximum fracture width without the occurrence of unfavorable phenomena (such as embedment). The results of this test were compiled together with the results of test no. 1, and are shown in Table 4. In case of steel plug test, the fracture width packed with proppant $W_{f}$ is $2.430 \mathrm{~mm}$, while for the rock saturated with fracturing fluid, the gap width equals $2.137 \mathrm{~mm}$. This means that in case of a shale rock a reduction of the maximum possible fracture aperture by $12.1 \%$ was achieved, and the effective width of fracture EWF was $87.9 \%$ (Table 4).

The total average depth of proppant embedment for the fracture $H_{e_{t}}$ given in table no. 4 was calculated as a sum of the average depths of proppant embedment in the top and bottom fracture faces (Table 2). The total penetration depth of proppant grains into the walls of the fracture $H_{e_{t}}$ was $0.141 \mathrm{~mm}$, while the total height of the impression of rock material out of the rock face $H_{w_{t}}$ was $0.152 \mathrm{~mm}$. These phenomena resulted in a reduction of the maximum (original) possible fracture width by $0.293 \mathrm{~mm}$. 

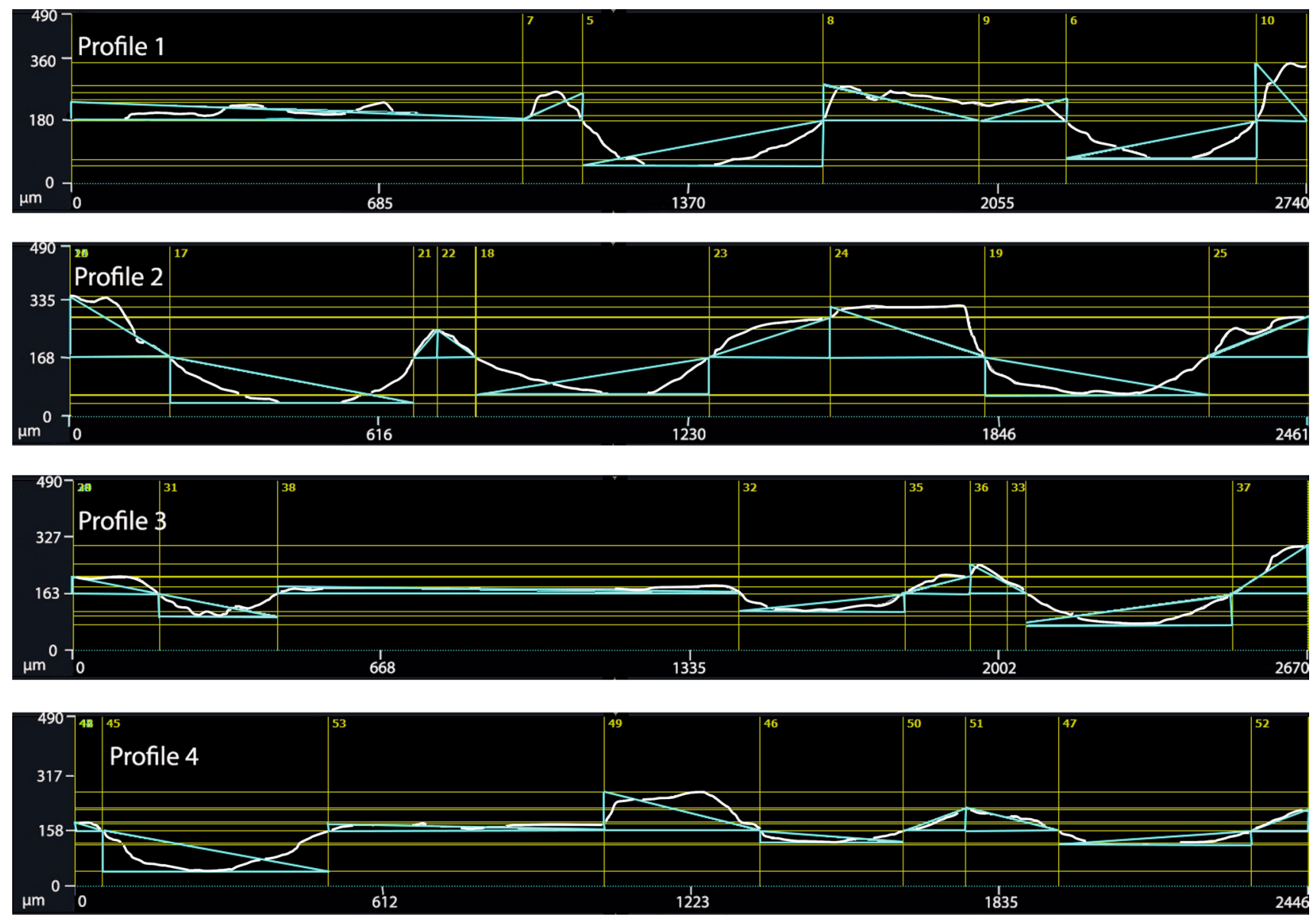

Fig. 13 Surface roughness profiles selected from the area 1 (Fig. 12) of top core face after embedment test

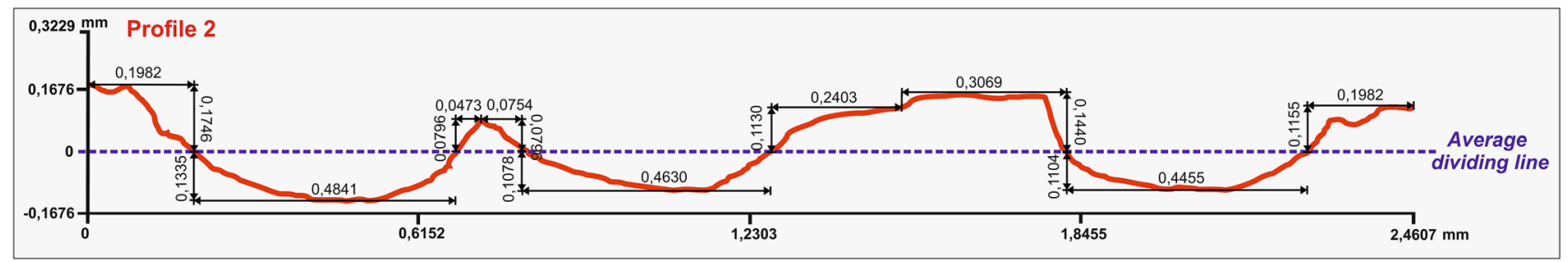

Fig. 14 Example of measured parameters of surface roughness on profile 2 from Fig. 13

\subsection{Statistical Significance of the Results}

To estimate statistical significance of the performed measurements, the example of two parameters $\left(H_{w}\right.$ and $\left.H_{e}\right)$ was implemented. In the calculations the following assumptions were made:

1. The results of all measurements follow the normal distribution.

2. For the top and bottom core samples five areas were selected in which the following measurements were performed:
- 50 measurements of embedment depth $\left(H_{w}\right)$ and 92 measurements of impressions height $\left(H_{e}\right)$ in the top core,

- 64 measurements of embedment depth $\left(H_{w}\right)$ and 127 measurements of impression height $\left(H_{e}\right)$ in the bottom core.

3. For each sample, the total profile lengths (L) and the average distances between the centers of embedment valleys and impression peaks were calculated (results in the Table 5). 
Table 5 Assumptions used for statistical calculations

\begin{tabular}{|c|c|c|c|c|}
\hline & \multicolumn{2}{|c|}{ Embedment (valleys) } & \multicolumn{2}{|c|}{ Impressions (peaks) } \\
\hline & Top core & Bottom core & Top core & Bottom core \\
\hline Surface area of the core sample, $\left(\mathrm{mm}^{2}\right)$ & 506.45 & 506.45 & 506.45 & 506.45 \\
\hline Amount of measurements, (dimensionless value) & 50 & 64 & 92 & 127 \\
\hline Total profile length $(\mathrm{L}),(\mathrm{mm})$ & 49.76 & 51.58 & 49.76 & 51.58 \\
\hline Average distances between the centers of embedment valleys and impression peaks, $(\mathrm{mm})$ & 0.99 & 0.81 & 0.54 & 0.41 \\
\hline Maximal number of peaks and valleys on the surface $\left(N_{\mathrm{P}}\right)$, (dimensionless value) & 511 & 780 & 1731 & 3071 \\
\hline Critical value for a confidence level $\left(\mathrm{U}_{0,95}\right)$, (dimensionless value) & 1.96 & 1.96 & 1.96 & 1.96 \\
\hline Fraction $(f),($ dimensionless value $)$ & 0.5 & 0.5 & 0.5 & 0.5 \\
\hline Minimum sample size $\left(N_{\min }\right)$, (dimensionless value) & 50 & 64 & 92 & 127 \\
\hline Error of estimation $(e),(\%)$ & 13.16 & 11.74 & 9.94 & 8.51 \\
\hline
\end{tabular}

4. The surface area of the top and bottom core samples were calculated (506.45 $\mathrm{mm}^{2}$ each).

5. For the measured surface area of the cores and the mean distances between peaks and valleys, the maximum number of them for each sample was counted. These values were considered to be the population sizes of all possible measurement results on the given samples.

6 . It was calculated for which error of estimation " $e$ ", the theoretical minimum number of measurements will be equal to the true number of measurements made.

7. With use of formula (9) the error of estimation was calculated (Table 5).

$N_{\text {min }}=\frac{N_{P}\left(U_{0,95}^{2} \cdot f(1-f)\right)}{N_{P} \cdot e^{2}+U_{0,95}^{2} \cdot f(1-f)}$,

where: $N_{\min }$ minimum sample size, (dimensionless value), $N_{P}$ size of the sampled population, (dimensionless value), $U_{0,95}$ the critical value for the confidence level of 0.95 results in a normal distribution, (dimensionless value), $f$ fraction, (dimensionless value), $e$ error of estimation, (\%).

The value of the fraction $-f$ and the maximum error- $e$ should be in the range $0-1$. In the analyzed case, the fraction in a given population was unknown; therefore, its value was assumed to be 0.5 . For the assumed significance level of $95 \%$, the critical value for the normal distribution-1.96 was used in the formula. The performed calculations showed that the estimation error was in the range 8.51-13.16\%.

\section{Discussion}

The mechanical properties of the examined rock (i.e. the static Young's modulus E), specified for deposit temperature and stress conditions, determine the rock stiffness, and as a consequence, the embedment susceptibility. As was stated before, the rock with an increased content of clay minerals and increased plasticity (brittleness below 30\%) is characterized by significantly reduced susceptibility to hydraulic fracturing (Rickman et al. 2008) and requires special stimulation techniques, including better filling with proppant material during fracturing.

Chen et al. have compared, with use of the developed modelling method, the Young's modulus of the rock and the proppant (Chen et al. 2018). They stated that decrease of the ratio of Young's modulus of the rock to the proppant causes increase of the proppant embedment depth. Alramahi and Sundberg (2012) correlate shale rock mineralogy, mechanical properties, fluid composition and proppant embedment to facilitate a prediction of the amount of conductivity loss due to proppant embedment in a variety of unconventional resource plays worldwide. However, due to the very large diversity of reservoir conditions and the multiplicity of factors affecting the reduction of conductivity, these tests cannot be considered as universal. If, based on Alramahi and Sundberg (2012) results, we would like to determine the proppant embedment, taking into account the content of clay minerals in rock, with the assumed pressure, the obtained embedment value would be about $0.8 \mathrm{~mm}$. Our experiment showed, however, significantly lower values of embedment, i.e., $0.071 \mathrm{~mm}$. The main reason is the different measurement 
conditions; for example, the Alramahi and Sundberg test is carried out between a steel plug and rock core, for 1 proppant layer, while in our experiment the embedment takes place between two rock cores, filled with proppant forming about 4 layers. The main reason of discrepancy is probably the difference in experiment temperature (room temperature versus $96{ }^{\circ} \mathrm{C}$ ) and the liquid soaking of the rock samples. The mentioned authors applied rock soaking with brine $(\mathrm{KCl})$ for $24 \mathrm{~h}$, while in our experiment the sample was soaked with fracturing fluid for $105 \mathrm{~min}$, which is much more likely the real conditions of stimulation. As should be expected, more fluid presence in the fracture zone leads to a change in the material properties, causing increase in plasticity, and therefore an increase in the embedment depth (Mueller and Amro 2015). The example presented above indicates that it is not possible to easily provide universal relations between the mechanical properties of rock and proppant embedment. Determining the size of this phenomenon requires detailed investigations carried out for specific deposit conditions and applied stimulation technologies.

There is the huge number of factors affecting the studied phenomenon, hence the correlation between the research results carried out by different researchers, and even the same researcher, but for different experiment conditions is not easy. Terracina et al., experimented with various proppants and three types of shale (Fayetteville, Bakken and Haynesville) (Terracina et al. 2010). The comparison of their conditions with those of our experiment is given in Table 6 .

The embedment depth, which was obtained in this study, should be considered as not very high, taking into account the general assumption that proppant embedment ranges from minimal in hard formations to typically as much as $1 / 2$ grain diameter in "soft formations" (LaFollette 2010). Zhang et al. (2015) stated that the average embedment depth was about $50 \%$ of the proppant median diameter in fractures that were exposed to water, while the average embedment depth was just $15 \%$ of the proppant median diameter in fractures that were only exposed to gas. In the case of our studies, the proppant grain size was between 0.850 and $0.425 \mathrm{~mm}$ (medium grain size $0.673 \mathrm{~mm}$ ), while the total effective penetration depth of proppant grains into the walls of the fracture was $0.293 \mathrm{~mm}$. This gives a value of embedment as about $40 \%$ of proppant grain diameter.

This result indicates the proper selection of proppant and fracturing fluid for the properties of the rock and the reservoir conditions. During the experiment performed here, there was also no evidence of intense phenomenon of crushing the proppant grains, which further reinforces the belief that the right filling material was chosen.

\section{Conclusions}

The conclusions resulting from the conducted research can be presented in three points, which are as follows:

\subsection{Detailed Results of the Tests Carried Out}

The performed tests were carried out for rock samples presaturated with fracturing fluid. Simulation of the embedment process shows ductile shale rock behavior, caused by relatively high clay minerals content.

The total penetration depth of ceramic proppant into the shale rock was estimated at about $40 \%$ of proppant grain diameter. This value is low in relation to that usually obtained in soft formations $50 \%$ of proppant grain diameter.

Table 6 List of experimental works on embedment phenomenon in shale rocks

\begin{tabular}{|c|c|c|c|c|c|c|c|c|}
\hline Reservoir rock & Fracturing fluid & Proppant & $\begin{array}{l}\text { Surface con- } \\
\text { centration of } \\
\text { proppant } \\
\left(\mathrm{kg} / \mathrm{m}^{2}\right)\end{array}$ & Times (days) & $\begin{array}{l}\text { Tem- } \\
\text { perature } \\
\left({ }^{\circ} \mathrm{C}\right)\end{array}$ & $\begin{array}{l}\text { Compressive } \\
\text { stress (MPa) }\end{array}$ & $\begin{array}{l}\text { Embedment } \\
\text { depth }(\mathrm{mm})\end{array}$ & Source \\
\hline Shale rock & Slickwater & $\begin{array}{l}\text { Sand } \\
40 / 70\end{array}$ & 0.98 & $1 / 4$ & 25 & 41.4 & 0.208 & Masłowski (2015) \\
\hline Shale rock & Slickwater & $\begin{array}{l}\text { LWC } \\
40 / 70\end{array}$ & 0.98 & $1 / 4$ & 25 & 68.9 & 0.256 & $\begin{array}{c}\text { Masłowski and } \\
\text { Biały (2016) }\end{array}$ \\
\hline Shale rock & Linear gel & $\begin{array}{l}\text { LWC } \\
30 / 50\end{array}$ & 2.44 & $1 / 4$ & 70 & 48.3 & 0.045 & $\begin{array}{l}\text { Masłowski et al. } \\
\text { (2018) }\end{array}$ \\
\hline Shale rock & $\begin{array}{l}\text { No fracturing } \\
\text { fluid (dry rock) }\end{array}$ & $\begin{array}{l}\text { LWC } \\
30 / 50\end{array}$ & 2.44 & $1 / 4$ & 70 & 48.3 & 0.013 & $\begin{array}{l}\text { Masłowski et al. } \\
\text { (2019) }\end{array}$ \\
\hline Bakken Shale & No data & $\begin{array}{l}\text { LWC } \\
20 / 40\end{array}$ & 9.76 & 5 & 135 & 58.6 & 0.113 & $\begin{array}{l}\text { Terracina et al. } \\
\text { (2010) }\end{array}$ \\
\hline Haynesville Shale & No data & $\begin{array}{l}\text { LWC } \\
40 / 80\end{array}$ & 9.76 & 3 & 148 & 69.0 & 0.202 & \\
\hline Baltic Basin shale & $\begin{array}{l}\text { Crosslinked frac- } \\
\text { turing fluid }\end{array}$ & $\begin{array}{l}\text { ISP } \\
20 / 40\end{array}$ & 4.88 & $1 / 4$ & 96 & 65.5 & 0.071 & This study \\
\hline
\end{tabular}


Comparing the obtained results of embedment phenomenon for steel plugs and examined shale rock, it could be stated that in the case of a rock the reduction of the maximum possible fracture aperture by $12.1 \%$ was achieved, hence the effective width of fracture with proppant material after hydraulic fracturing was 87.9.

The obtained results of a relatively low total effective penetration depth of proppant grains into the walls of the fracture $(0.293 \mathrm{~mm})$, and high effective width of fracture with proppant material after hydraulic fracturing (87.9\%), indicate the proper selection of proppant and fracturing fluid for the properties of the rock and the reservoir conditions.

To estimate statistical significance of the performed measurements, the example of two parameters $\left(H_{w}\right.$ and $\left.H_{e}\right)$ was implemented. The performed calculations showed that the estimation error was in the range of 8.51-13.16\%.

\subsection{The Novelty of the Presented Examinations}

The proppant embedment tests were for the first time performed on Baltic Basin shale for conditions corresponding to the average reservoir conditions occurring in the studied deposit formation.

The results of performed experiments include a range of embedment parameters, that have not been widely described in the literature so far. They are: the size of the fracture gap (fracture width), damage to the fracture face surface as a result of the phenomenon of embedment (i.e. $\mathrm{DF}_{e_{t}}$ ). Another important aspect of the presented research is the incorporation of not only the phenomenon of embedment, but also impression of the rock material into the fracture zone.

The novel laboratory imaging procedure was implemented to the proppant embedment visualization. This procedure proved to be suitable for assessing the vulnerability of a deposit rock to the embedment phenomenon.

\subsection{General Remarks}

The embedment phenomenon is one of the more important parameters determining the maintenance of effective fracture aperture after hydraulic fracturing, in particular in unconventional deposits. This phenomenon is determined by a range of parameters, which are, among others: proppant type, proppant amount, hydraulic fracturing technology, temperature and compressive stress conditions in the deposit, etc.

The above conditions mean that it is not possible to use universal data to determine the size of the embedment. Hence to determine the parameters of this phenomenon the detailed investigations should be carried out for specific deposit conditions and applied stimulation technologies.

The presented study is a preliminary stage of comprehensive research on embedment phenomenon in shale rocks.
The implemented novel experimental procedure will be used in the next stages of research to provide a parametric study of embedment process and find the correlation between the confining parameters, e.g. rock geomechanical propertiesand the embedment depth.

Author contributions Research concept: MM. Methodology: MM and ML. Software: MM. Formal analysis: MM and ML. Investigation: MM. Writing and editing: MM and ML. Images: MM and ML.

Funding This paper is based on the results from statutory work realized at the Oil and Gas Institute, National Research Institute, Poland. Archive no. DK-4100-11/18.

Availability of Data and Material Data will be available on demand.

\section{Declarations}

Conflict of interest The authors declare that they have no known competing financial interests or personal relationships that could have appeared to influence the work reported in this paper.

Open Access This article is licensed under a Creative Commons Attribution 4.0 International License, which permits use, sharing, adaptation, distribution and reproduction in any medium or format, as long as you give appropriate credit to the original author(s) and the source, provide a link to the Creative Commons licence, and indicate if changes were made. The images or other third party material in this article are included in the article's Creative Commons licence, unless indicated otherwise in a credit line to the material. If material is not included in the article's Creative Commons licence and your intended use is not permitted by statutory regulation or exceeds the permitted use, you will need to obtain permission directly from the copyright holder. To view a copy of this licence, visit http://creativecommons.org/licenses/by/4.0/.

\section{References}

Akrad O, Miskimins J, Prasad M (2011) The effects of fracturing fluids on shale rock mechanical properties and proppant embedment. Paper Society of Petroleum Engineers presented at Annual Technical Conference and Exhibition, 30 October-2 November, Denver, Colorado, USA SPE-146658-MS. https://doi.org/10.2118/14665 8-MS

Alramahi B, Sundberg MI (2012) Proppant embedment and conductivity of hydraulic fractures in Shales. Am Rock Mech Assoc ARMA 12-291:1-6

American Petroleum Institute (1989) Recommended practices for evaluating short-term proppant-pack conductivity 61 . American Petroleum Institute, Washington

Bandara KMAS, Ranjith PG, Rathnaweera TD (2019) Improved understanding of proppant embedment behavior under reservoir conditions: a review study. Powder Technol 352:170-192

Barree RD, Conway MW (2009) Multiphase non-darcy flow in proppant packs. SPE Prod Oper 24:257-268. https://doi. org/10.2118/109561-PA (SPE-109561-PA)

Barree RD, Miskimins J, Conway MW, Duenckel R (2018) Generic correlations for proppant pack conductivity. Soc Petrol Eng. https ://doi.org/10.2118/179135-PA (SPE-179135-PA) 
Chen M, Zhang S, Liu M, Ma X, Zou Y, Zhou T, Li N, Li S (2018) Calculation method of proppant embedment depth in hydraulic fracturing. Petrol Explor Dev 45:159-166. https://doi.org/10.1016/ S1876-3804(18)30016-8

Czupski M, Kasza P, Wilk K (2013) Fluids for fracturing unconventional reservoirs. Nafta-Gaz 1:42-50

Deng S, Li H, Ma G, Huang H, Li X (2014) Simulation of shale-proppant interaction in hydraulic fracturing by the discrete element method. Int J Rock Mech Min Sci 70:219-228

Denney D (2012) Fracturing-fluid effects on shale and proppant embedment. Soc Petrol Eng J Petrol Technol 64:59-61. https://doi. org/10.2118/0312-0059-JPT (SPE-0312-0059-JPT)

Donaldson E, Alam W, Begum N (2013) Hydraulic fracturing explained: evaluation, implementation and challenges. Elsevier

Economides MJ, Nolte KG (2000) Reservoir stimulation, 3rd edn. Wiley

Ghassemi A, Suarez-Rivera R (2012) Sustaining fracture area and conductivity of gas shale reservoirs for enhancing long-term production and recovery, research partnership to secure energy for America. Final Report of Project 08122

Gou X, Guo J, Lu C, Chen S (2017) A new method of proppant embedment experimental research during shale hydraulic fracturing. Electron J Geotech Eng 22:1473-1482

Grieser B, Bray J (2007) Identification of production potential in unconventional reservoirs. Paper Society of Petroleum Engineers presented at Production and Operations Symposium, 31 March-3 April, Oklahoma City, Oklahoma USA SPE 106623, 1-6, DOI: https://doi.org/10.2118/106623-MS

Gutierrez M, Nygard R (2008) Shear failure and brittle to ductile transition in shales from P-wave velocity. In: Proceedings of the 42nd US rock mechanics symposium (USRMS) San Francisco, California; 29 June-2 July, ARMA 198

Kasza P (2013) Effective fracturing of shales in Poland. Nafta-Gaz 11:807-813

Klimuszko E (2002) Silurian sediments from SE Poland as a potiential source rocks for Devonian oils. Biuletyn Państwowego Instytutu Geologicznego 402:75-100

Lacy LL, Rickards AR, Ali SA (1997) Embedment and fracture conductivity in soft formation associated with HEC, borate and water-based fracture design. Paper Society of Petroleum Engineers presented at Annual Technical Conference and Exibition 5-8 October, San Antonio, Texas

LaFollette R (2010) Key considerations for hydraulic fracturing of Gas Shales. Online Webinar presented at the AAPG E-Seminar 9

Lee DS, Elsworth D, Yasuhara H, Weaver JD, Rickman R (2010) Experiment and modelling to evaluate the effects of proppantpack diagenesis on fracture treatments. J Petrol Sci Eng 74:67-76. https://doi.org/10.1016/j.petrol.2010.08.007

Masłowski M (2015) Studies of the embedment phenomenon after the hydraulic fracturing treatment of unconventional reservoirs. Nafta-Gaz 7:461-471

Masłowski M, Biały E (2016) Studies of the embedment phenomenon in stimulation treatments. Nafta-Gaz 12:1101-1106. https://doi. org/10.18668/NG.2016.12.13

Masłowski M, Czupski M (2014) Basic properties of proppants used in hydraulic fracturing treatments of hydrocarbon deposits. Przegląd Górniczy 12:44-50 (in Polish)

Masłowski M, Kasza P, Czupski M (2016) Studies of the susceptibility of the tight gas rock to the phenomenon of embedment, limiting the effectiveness of hydraulic fracturing. Nafta-Gaz 10:822-832. https://doi.org/10.18668/NG.2016.10.07

Masłowski M, Kasza P, Wilk K (2018) Studies on the effect of the proppant embedment phenomenon on the effective packed fracture in shale rock. Acta Geodynamica et Geomaterialia 15:105-115. https://doi.org/10.13168/AGG.2018.0012
Masłowski M, Kasza P, Czupski M, Wilk K, Moska R (2019) Studies of fracture damage caused by the proppant embedment phenomenon in shale rock. Appl Sci Basel 9:1-14. https://doi.org/10.3390/ app9112190

Morales H (2012) Sustaining fracture area and conductivity of gas shale reservoirs for enhancing long-term production and recovery. In: RPSEA Unconventional Gas Conference: Geology, the Environment, Hydraulic Fracturing, Canonsburg, 17-18.IV.2012

Mueller M, Amro M (2015) Indentaion Hardness for Improved Proppant Embedment Prediction in Shale Formation. Paper Society of Petroleum Engineers presented at the SPE European Formation Damage Conference and Exhibition, 3-5 June, Budapest Hungary SPE 174227-MS. https://doi.org/10.2118/174227-MS

Poprawa P (2010) Shale gas potential of the Lower Palaeozoic complex in the Baltic and Lublin-Podlasie basins (Poland). Przegląd Geologiczny 58:226-249 (in Polish)

Reinicke A, Legarth B, Zimmermann G, Huenges E, Dresenn G (2006) Hydraulic fracturing and formation damage in a sedimentary geothermal reservoir. Paper presented at Enhanced Geothermal Innovative Network for Europe Workshop 3 Stimulation of reservoir and microseismicity, Kartause Ittingen, Zürich, June 29-July 1 Switzerland

Reinicke A, Rybacki E, Stanchits S, Huenges E, Dresen G (2010) Hydraulic fracturing stimulation techniques and formation damage mechanisms-implications from laboratory testing of tight sandstone-proppant systems. Chemie der Erde Geochemistry 70:107-117. https://doi.org/10.1016/j.chemer.2010.05.016

Rickman R, Muller M, Petre E, Grieser B, Kundert D (2008) SPE and Halliburton, A Practical Use of Shale Petrophysics for Stimulation Design Optimization: All Shale Plays Are Not Clones of the Barnett Shale. Paper Society of Petroleum Engineers presented at Annual Technical Conference and Exhibition, 21-24 September, Denver, Colorado USA SPE 115258, https://doi. org/10.2118/115258-MS

Sato K, Wright Ch, Ichikawa M (1998) Post-Frac analysis indicating multiple fractures created in a volcanic formation. Paper Society of Petroleum Engineers presented at the SPE India Oil and Gas Conference and Exhib, 17-19 Feb New Delhi India SPE 39513MS. https://doi.org/10.2118/39513-MS

Singh VK, Wolfe C, Jiao D (2019) Fracturing fluids impact on unconventional shale rock mechanical properties and proppant embedment. American Rock Mechanics Association, 53rd U.S. Rock Mechanics/Geomechanics Symposium, 23-26 June New York

Smith MB, Montgomery CT (2015) Hydraulic fracturing. CRC Press Taylor \& Francis Group, Boca Raton (ISBN-13: 978-1-4665-6685-9)

Speight JG (2016) Handbook of hydrualic fracturing. Wiley \& Sons, New Jersey

Tang Y, Ranjith PG, Perera MSA (2018) Major factors influencing proppant behaviour and proppant-associated damage mechanisms during hydraulic fracturing. Acta Geotech 13:757-780. https://doi. org/10.1007/s11440-018-0670-5

Terracina JM, Turner JM, Collins DH, Spillars SE (2010) Proppant selection and its effect on the results of fracturing treatments performed in shale formations. In: Paper Society of Petroleum Engineers presented at Annual Technical Conference and Exhibition, 19-22 September, Florence Italy SPE 135502 https://doi. org/10.2118/135502-MS

Weaver JD, Parker M, van Batenburg DW, Nguyen PD (2007) Fracture-related diagenesis may impact conductivity. SPE J 12(03):272-281

Wen Q, Zhang S, Wang L, Liu Y, Li X (2007) The effect of proppant embedment upon the long-term conductivity of fractures. J Petrol Sci Eng 55:221-227

Zhang J, Ouyang L, Zhu D, Hill AD (2015) Experimental and numerical studies of reduced fracture conductivity due to proppant 
embedment in the shale reservoir. J Petrol Sci Eng 130:37-45. https://doi.org/10.1016/j.petrol.2015.04.004
Publisher's Note Springer Nature remains neutral with regard to jurisdictional claims in published maps and institutional affiliations. 